\title{
SECURITIZATION OF MIGRATION: THE CASE OF TURKEY-EU RELATIONS*
}

\section{Sinem YÜKSEL ${ }^{* *}$}

\section{Abstract}

This article aims at analyzing "securitization of migration" in TurkeyEuropean Union (EU) relations. The Copenhagen School's theory of securitization, multisectoral security approach and speech act are given special emphasis in this regard. The major argument of this article is that the EU has securitized migration from Turkey mainly for political reasons; thus, securitization of migration in Turkey-EU relations is a political choice. Firstly, it is aimed to set theoretical foundation of the article and the special reference is given to the Copenhagen School's securitization theory. Then, securitization of migration in Turkey-EU relations is examined by special emphasis on internal security, cultural identity and welfare state. Accordingly, conclusion of this article is that the securitization of migration in Turkey-EU relations does not depend on real existential threats and the EU has securitized migration from Turkey for political reasons.

Keywords: Turkey-EU relations, migration, securitization, internal security, cultural identity, welfare state

\section{GÖÇÜN GÜVENLIKKLEŞTİRILMESI: TÜRKIYYE-AVRUPA BİRLİĞİ ILIŞKILLERI ÖRNEĞí}

$\ddot{O} z$

Bu makalenin amacı, Türkiye-Avrupa Birliği (AB) ilişkilerinde göçün güvenlikleştirilmesini incelemektir. Bu doğrultuda, Kopenhag Ekolü' nün güvenlikleştirme teorisi, çok-sektörlü güvenlik yaklaşımı ve söz eylemin rolü üzerinde durulmuştur. Bu makalenin ana argümanl, AB'nin Türkiye'den gelen göçü özellikle siyasi nedenlerle güvenlikleştirdiğ $i$ ve bundan dolayı da Türkiye-AB ilişkilerinde göçün güvenlikleştirilmesinin siyasi bir seçim olduğudur. Illk önce

\footnotetext{
* This article is revised and abridged version of the MA thesis submitted to the European Union Institute of Marmara University in 2013.

${ }^{* *}$ MA, Marmara University, European Union Institute, Department of EU Politics and International Relations, e-mail: sinemyuksel85@hotmail.com
} 
makalenin teorik çerçevesini çizmek amaçlanmış ve Kopenhag Ekolü' nün güvenlikleştirme teorisi özellikle vurgulanmıştır. Sonra, Türkiye-AB ilişkilerinde göçün güvenlikleştirilmesi iç güvenlik, kültürel kimlik ve refah devleti vurgulanarak incelenmiştir. Buna göre bu çalışmanın sonucu, Türkiye-AB ilişkilerinde göçün güvenlikleştirilmesinin gerçek varoluşsal nedenlere dayanmadığı ve AB'nin Türkiye'den gelen göçü politik sebeplerle güvenlikleştirdiğidir.

Anahtar Kelimeler: Türkiye-AB İlişkileri, göç, güvenlikleştirme, iç güvenlik, kültürel kimlik, refah devleti

\section{Introduction}

The objective of this article is to analyse "securitization of migration" in Turkey's relations with the EU and to evaluate whether it is a political choice on the part of the Union or not. The Copenhagen School's theory of securitization and the role of speech act are specifically referred to for their social constructivist structure. Its major argument is that the EU has securitized migration from Turkey mainly for political reasons; thus, the securitization of migration in Turkey-EU relations is a political choice.

This article focuses mainly on security, securitization, migration and the issue of migration in Turkey-EU relations. Identifying security and securitization is significant for constructing theoretical framework of the article. In this article, security is seen as a process of "social construction of threats" (Buzan, Wæver and de Wilde, 1998: 34) via speech acts; that is, securitization. The Copenhagen School states: "The process of securitization is what in language theory is called a speech act" (Buzan, Wæver and de Wilde, 1998: 26). In addition, securitization starts by declaring something as a threat. Therefore, speeches of political actors/politicians are examined in terms of securitization of migration. Thus, theoretical framework is applied to practice.

In addition, Jef Huysmans' conceptualization of securitization on three related themes - internal security, cultural identity and welfare state - is used as the framework to show how the EU securitizes migration in its relations with Turkey. In this context, internal security, cultural identity and welfare state are analysed in detail as referent objects.

On the other hand, some statistics are also used to prove that there is no need for securitization. Europe's population is aging, and they need labour force to maintain the sustainability of internal market and welfare state. Therefore, the prospect of Turkish migration in case of full membership does not pose a threat against the internal market and welfare state.

This article also uses some findings of econometric studies, which estimate Turkish migration towards Europe in the following years. They also show that 
there is no need to fear Turkish migration, because "[t]he experiences of Greece, Portugal, and Spain indicate that a successful accession period with high growth and effective implementation of the reforms reduces and gradually eliminates the migration pressures. There is no a priori reason why Turkey would not go through a similar experience" (Erzan, Kuzubaş ve Yıldız, 2004: 124). On the other hand, it is estimated that the growth of Turkish population will also decrease; therefore, the fear of huge population movements from Turkey to Europe, as many European politicians refer in their speeches, becomes unjustifiable and unreasonable.

To sum up, this article aims to analyse securitization of migration in TurkeyEU relations from the perspective of the Copenhagen School's security approach to show how migration turned into a security issue and to what extent the EU securitizes migration and its implications on Turkey-EU relations.

\section{Security and Securitization from the Perspective of the Copenhagen School}

Security - as concept without a commonly agreed definition - is defined differently by different theoretical approaches. The Copenhagen School conceptualizes the term security in three ways. Firstly, Buzan argues that security is an "essentially contested concept" referring to W. B. Gallie, because this term like the others; love, power, justice peace, etc. - has caused unsolvable debates in their applications and meanings (Buzan, 2007: 29). Secondly, Waever describes security as "a specific way of framing an issue" (Wæver, 1996: 106) and finally refers to it as a "speech act" (Wæver, 1995: 55). Wæver points out:

\footnotetext{
With the help of language theory we can regard 'security' as a speech act. In this usage, security is not of interest as a sign that refers to something more real; the utterance itself is the act. By saying it, something is done (as in betting, giving a promise naming a ship). By uttering 'security,' a state representative moves a particular development into a specific area, and thereby claims a special right to use whatever means are necessary to block it (Wæver, 1995: 55).
}

The Copenhagen School has tried to find answers to the basic question, "What quality makes something a security issue in international relations?" (Buzan, Wæver and de Wilde, 1998: 21). They argue that security is about survival and if there is an existential threat against designated referent object (it may be state, territory, nation, environment, and so on) there is also a security matter and extraordinary measures are needed to cope with this security matter (Buzan, Wæver and de Wilde, 1998: 21). At this point, it is important to determine who decides on existential threats and extraordinary measures. Because not everybody has the same effectiveness in the public sphere, they must be state representatives or elites (Williams, 2003: 514). This case shows how securitization will occur as a result of a speech act.

Securitization ensures that something is perceived as a security matter; that is, making something a security issue is securitization (Buzan, Wæver and de Wilde, 1998: 21). In considering something as a security issue, the main point is the presence of an existential threat. The reason is that when it is defined as existential, 
there must be an absolute priority and extraordinary measures are needed. Yet, the securitizing actor - power holder- may use securitization to gain control over any issue; hence, securitization can be based not only on a real existential threat but also on a perceived threat (Wæver, 1995: 54). That is, the security label is sometimes used although there is no problem. It is simply because, declaring something as a security issue, is a political choice (Wæver, 1995: 65).

On the other hand, speech act is important in the process of securitization, because securitization starts by declaring something as a threat and turning something into a security issue. Furthermore, security is regarded as a speech act (Wæver, 1995: 55). An actor changes the topic when he talks about security; in such case the topic is no longer about politics but refers to security concerns; thereby, the actor legitimates extraordinary means against socially constructed threat. Therefore, security is socially constructed and it is self-referential (Buzan, Wæver and de Wilde, 1998: 24), because the issue is presented as a threat. When the speech act is used, the matter becomes a security issue in this regard.

Consequently, the Copenhagen School contends that securitization is an extreme version of politicization that enables the use of extraordinary means in the name of security (Buzan, Wæver and de Wilde, 1998: 23). It is a way of framing and handling an issue (Wæver, 1996: 106). In this sense, it can be argued that securitization is in fact a political choice. As Williams pointed out:

Focusing on the speech act highlights the decision to securitize an issue. While the background conditions for enabling securitization to take place must exist, a focus on decision highlights the explicitly political nature of such a choice. Securitization can never be reduced to the conditions of its social accomplishment: it is an explicitly political choice and act (Williams, 2003: 520).

\section{Securitization of Migration in Turkey-EU Relations: The Case of Internal Security}

The notion of internal security in the EU has largely been derived from the establishment of the internal market and especially from the securitization of migration in the case of the internal market. As the internal market was established, internal border controls were eliminated, and the external frontiers were strengthened. As Huysmans argues, "border controls have played a key role in the spill-over of the socio-economic project of the internal market into an internal security project" (Huysmans, 2006: 70). In this sense, an important issue came to the fore: migration.

Turkey-EU relationship has been established on the basis of association in 1963 when the Ankara Association Agreement was signed with the European Economic Community (EEC). Considering migration from Turkey to the EEC countries, Article 12 of the Ankara Agreement set an aim for "progressively securing freedom of movement for workers between them" (Ankara [Association] Agreement, 1973: Article 12). This was an important step in terms of gradually ensuring free movement of people. Furthermore, the Additional Protocol that was 
signed in 1970 regulated the issue of free movement of workers in Article 36 as "[f]reedom of movement for workers between Member States of the Community and Turkey shall be secured by progressive stages in accordance with the principles set out in Article 12 of the Agreement of Association between the end of the twelfth and the twenty-second year after the entry into force of that Agreement" (Additional Protocol, 1973: Article 36).

Free movement of workers, however, was not put into practice timely -i.e. in the year 1986 as stated in the Additional Protocol-, because relations between Turkey and the EC worsened due to economic stagnation in 1970s and political developments in Turkey in 1980s. In addition, although relations improved, free movement of labour has not been achieved due to several reasons; especially for the fear of the prospect of large-scale migration flows from Turkey to the EU.

After the EU's declaration of Turkey as a candidate country, some discussions took place on the probable implications of Turkey's accession. Many people in Europe have believed that there would be a large amount of migration after Turkey's accession to the EU (Erzan and Kirişçi, 2004: 2). A Finnish diplomat who was quoted by Duner in her study stated "Are you people up here in Finland really ready to have five million or so Turkish immigrant workers coming in as soon as the ink is dry on the accession agreement?" (Cebeci, 2004: 199). This statement is a clear speech act that starts securitization of migration (Cebeci, 2004: 199). Finnish diplomat - as a securitizing actor - tried to show Turkey's accession into the EU as a threat by an exaggerating argument (Cebeci, 2004: 199), because the argument that five million Turkish migrants heading only to Finland is not reasonable. Additionally, this statement has a negative connotation (Cebeci, 2004: 199). Another negative phrase was that, approximately 17 million Turks would migrate to Europe if they could, stated in a column in the Belgian paper (De Standard) by Dirk Jacob Niewboer (Erzan and Kirişçi, 2004: 2). On the other hand, the negative connotations regarding free circulation of people emerged in the context of Turkey's accession negotiations and had repercussions in official documents. For example, an official document states:

[...] with over three million, Turks constitute by far the largest group of third country nationals legally residing in today's EU. Available studies give varying estimates of expected additional migration following Turkey's accession. Long transition periods, and a permanent safeguard clause can be considered to avoid serious disturbances on the EU labour market (Recommendation of the European Commission on Turkey's Progress Towards Accession, 2004: 5).

In addition, the Negotiation Framework Document has a negative wording regarding free movement of persons. $12^{\text {th }}$ principle of the Document states:

Long transitional periods, derogations, specific arrangements or permanent safeguard clauses, i.e. clauses which are permanently available as a basis for safeguard measures, may be considered. The Commission will include these, as appropriate, in its proposals in areas such as freedom of movement of persons, structural policies or agriculture. Furthermore, the decision-taking process regarding the eventual establishment of freedom of movement of persons should allow for a maximum role of individual Member States. Transitional arrangements or safeguards should be reviewed regarding 
their impact on competition or the functioning of the internal market (Principles Governing Negotiations, 2005: 5).

All these mean that several measures can be taken against free movement of persons "when necessary" (İçduygu, 2011: 13).

On the other hand, some try to equate Turkish membership with an influx of Turkish migrants. However, fearing an influx of Turkish migrants after Turkey's full membership is unjustifiable. Several studies argue that Turkey's membership will not cause a large-scale population movement - unlike the Finnish diplomat's speech or the column in the Belgian paper - into the EU. It is estimated that migration from Turkey to the EU would be 2.7 million until 2030 in the longer term (Lejour, de Mooij and Capel, 2004: 11). Another econometric model states:

[...] net migration from Turkey to the EU-15 in the period 2004-2030 is between 1 and 2.1 million, foreseeing a successful accession period with high growth and free labour mobility starting 2015 - a rather optimistic assumption to explore the upper bound of the immigration potential. On the other hand, if Turkey's membership process is endangered and high growth cannot be sustained, 2.7 million people may be penetrating the EU-15 despite the prevailing strict restrictions on labour mobility (Erzan, Kuzubaş ve Yildız, 2004: 115).

Those studies clearly show that there will not be a huge amount of migration towards Europe in the case of Turkish membership. What is more, migration trends from Turkey to Europe have decreased in the recent years. Classifying Turkish migration into terms clearly indicates this decline. Turkish labour migration towards Western Europe was intensive between the years 1961-1974. Yet, especially after the oil crisis in 1973, the pattern of this type of migration has changed as it turned into family reunification. The migration rates towards Europe have decreased gradually. What is more, the countries of immigration (where Turkish workers head) have changed in 1980s - the Arab countries - and in 1990s - the countries of the former Soviet Union (İçduygu, 2009: 358-359). According to Turkish Employment Organization's statistics, Turkish workers have headed the Middle Eastern and Arabic countries especially since the year 1980 (Türkiye İş Kurumu, 2012 Y1llik Tabloları, Tablo 37). This situation has remained unchanged in 1990s and 2000s (Türkiye İş Kurumu, 2012 Yıllık Tabloları, Tablo 37). In the meantime, Turkey did not remain only as a sending country but became a receiving country, too. This is an important point that must be kept in mind in terms of the EU's previous experiences. As İçduygu and Karaçay argue:

Considering that a similar process has been experienced by current EU Member States such as Portugal, Spain, Italy and Greece, it can be said that these new migratory processes [in the case of Turkey's prospective membership] can bring Turkey to a status that is parallel to those of such states in the European migration- and asylum-seeking regimes (İçduygu and Karaçay, 2012: 34).

Another similarity, with those EU members, can be the return migration after and as a result of Turkish accession to the EU. Kaya and Kentel clearly state: 
was experienced. It seems that the same could apply to the Turkish case. The proportion of those people who would consider going back to the homeland in the case of Turkey's membership to the Union is more than $30 \%$ in both countries (Kaya and Kentel, 2005: 119).

This is a significant rate considering the huge amount of Turkish migrants living in Germany. Although Turkey has been evaluated as having a general intention to migrate, still, it has "the least number of people with a specific intention to migrate. In this respect, only $0.3 \%$ of the population of Turkey has a specific intention to migrate in the following five years" (İçduygu and Karaçay, 2012: 32). In this sense, reliable studies prove that there will not be a large-scale migration from Turkey to the EU in the case of Turkey's membership. However, populist rhetoric affects the process of Turkey's membership via securitization of migration.

In the case of Turkey-EU relations, within the framework of the Copenhagen School's securitization theory, the threat is constructed as the free movement of Turkish workers (generally migration as a whole); the referent object is the internal market and the EU/Europe (i.e. European society and citizens) itself; securitizing actors are representatives of EU Member States; the audience is their nationals as well as the media and some civil society actors in Europe; and extraordinary measures are restrictive policies, permanent safeguards, long transition periods, derogations, specific arrangements, etc. despite the EU's clear commitments in the Ankara Agreement and the Additional Protocol.

\section{Securitization of Migration in Turkey-EU Relations: The Case of Cultural Identity}

The notion of belonging is predominant in identity issues. However, it is contested if Turkey is European or not mainly because of the way European countries define themselves and their others. Actually, definitions of Europe and Europeanness are also contested in themselves. As Müftüler-Bac argues: "Complicating Turkey's ambiguous relations with the EU is Europe's own identity crisis, which begs the question 'what is Europe?' Is it 'Atlantic Europe,' based on a collective defense, or is there a 'core Europe' with roots in ethnicity and culture?" (Müftüler-Bac, 2000: 22). If it is "Atlantic Europe" based on a collective defense, Turkey is seen as an ally - especially during the Cold War, Turkey was an important ally (Müftüler-Bac, 2000: 29). On the other hand, if there is a "core Europe" with roots in ethnicity and culture, Turkey is seen as an alien with its Asian and Islamic ties. In this context, Rumelili states:

[...] on the one hand, through its membership in Western/European institutions such as NATO and the Council of Europe, Turkey is considered as a part of Europe. On the other hand, as a predominantly Muslim country that is situated mostly in Asia, Turkey has been perceived as a threat to exclusive notions of European identity based on geography and Judeo-Christian culture" (Rumelili, 2003: 222).

It can be clearly understood that "[...] Turkey occupies a liminal, a partly-self, partly-other position. Turkey is often represented as a country of contradictions; 
[...]" (Rumelili, 2008: 102). Therefore, in the context of securitization of migration, Turkey is emphasized as the other and alien depending on some European leaders' attitudes. The reasons of perceiving Turks as "alien" or the "other" can be attributed to the historical image of Turks, integration problems of the first generation Turkish migrants and culturally different roots of them especially in religious terms.

Turks and Europeans did not have good neighbourly relations in the past. The relations between Turks and Europeans were full of wars and struggles/conflicts. Two of them are crucial in terms of defining Turks as the other. The first was the conquest of Istanbul in 1453. It is argued that Turks have been in Europe since 1453, yet they are "in but not of Europe" (Kylstad, 2010: 7). The statement explicitly shows that Turks are not seen as Europeans. The second was the siege of Vienna which has still affected attitudes towards Turkey. As Frits Bolkestein who was a European Commissioner stated: "If Turkey accedes to the EU, then this means that the efforts of the German, Austrian and Polish troops that resisted the Ottoman Turks' siege of Vienna in 1683 would be in vain" (Müftüler-Bac and Taşkın, 2007: 43). This is a clear securitizing act which has pointed to Turks as other/as threat. Similarly, Jörg Haider who was an Austrian politician asked: "For what reasons did our ancestors defend our country against the Turks if we are now letting them in again?" (Küçük, 2011: 16). By asking that, he has pointed to the historical other image of the Turks and tried to create a threat perception by this way; that is, he has issued a securitizing act, too.

On the other hand, the Ottoman Empire and its Muslim identity versus Christian Europe shaped relations between them. It is contended "Turkish peril was viewed as the latest phase in the centuries - old assault of Islam on Christianity" (Neumann, 1999: 44). In the light of these relations, Turks were even defined as barbarian. As Neumann and Welsh state: 'Europe represented 'civilised' world and the Ottomans belonged to the 'barbaric' world. It was claimed that the 'Turk' possibly did not belong to the progressive mankind" (Müftüler-Baç and Taşkın, 2007: 41). Neumann also argues: "[...] the dominant other in the history of the European state system remains 'the Turk,' and because the lingering importance of that system, we have here a particularly important other" (Neumann, 1999: 39-40). According to this argumentation, otherness of Turks has remained as in the past. While Europeanness of Turkey was not questioned during the Cold War for strategic and ideological reasons -then Europe's other was communism- the historical "images of Turks hammering on the gates of Vienna" was included in Turkey's relations with Europe when approaching the end of the Cold War (Verney, 2007: 216). Consequently, Turks are defined as barbarian, the other and non-European historically; that is why European societies still have a negative view of the Turks and EU Member States tend to establish a limited relationship with Turkey which depended on their own interests. This is also seen in the current relations and policies of European politicians; they use such a rhetoric regarding 
Turkey's full membership and more specifically, Turkish migrants who want to head Europe.

Integration problems of Turkish migrants also constitute an important problem and add to the securitization of migration. Depending on the previous experiences, many Europeans believe that Turks are not integrated into the host society. Hence, they do not tend to receive more Turks into their society, and securitize migration.

It is true that first generation migrants could not integrate into the host society well, which has basically two main reasons. First, those people who immigrated to Europe were generally from rural areas (Kirişçi, 2003). They were more conventional, protective and unskilled (Kirişçi, 2003). Second, neither home country nor host country put an effort to ensure integration of migrants into the host society, because according to the guest worker system, these migrants were expected to return to their homeland (Erzan and Kirişçi, 2004: 5).

On the other hand, the results of the study conducted by Kaya and Kentel show that the second and third generation migrants have integrated into the European society successfully (Kaya and Kentel, 2005: 71). Thus, it can be argued that the integration problem of Turkish migrants has been exaggerated to a certain extent. To increase the level of integration, political rights must be granted to migrants and political integration must be promoted. The reason is that political integration brings out active political relations and participation in the political life of the host country. Migrants get more involved with the host country's policies and become active participants. Consequently, once political integration is guaranteed, cultural integration follows it. Nevertheless, because Turkish guest workers were not given the chance of sufficient political participation, their integration into the host society has been harder. As Kaya argues:

The attribution of citizenship to migrants can very well be an efficient integration tool.
Immigrants attain the fullest degree of political rights if they become citizens of their
country of settlement. Granting migrants the right to elect and to stand as a candidate on
top of their social, civil and cultural rights (civic citizenship, or denizenship) has a great
potential to prompt them to wither away from mobilizing themselves along with ethnic,
cultural, religious and traditional lines, and thus to mobilize themselves along with
political parties of the country they reside in (Kaya, 2007: 4-5).

In addition, considering the fact that religion is an important component of Europeanness, securitization of cultural identity becomes more apparent. The reason is that throughout the history Europeans have always perceived Islam as a challenge. Especially after the 9/11 attacks, Islam became more prominent; it was even securitized. 9/11, Madrid and London attacks have made some Western (Christian, European and American) societies establish a link between Islam and terrorism mainly due to the religious motivations of perpetrators. As a result of these prejudgments, those societies started to perceive almost all Muslims as terrorists without evaluating if they were or not really terrorists. For example, in a survey it was pointed out that $83 \%$ of Germans equated "Islam" with "terrorism" 
(Intolerance and Discrimination against Muslim in the EU: Developments since September 2001, 2005: 76).

This was also a result of anti-Muslim approach emphasized in several speeches of European leaders. For example, on 19 October 2009, in a debate article in Sweden's biggest daily Aftonbladet, the party leader Jimmie Akesson wrote: "The Muslims are our greatest threat - as a Swedish Democrat, I see this as our greatest foreign threat since the Second World War and I promise to do all within my power to turn this trend when we go to elections" (Spongenberg, 2010). An antiimmigrant populist politician of the Netherlands, Geert Wilders, has founded an International Freedom Alliance with the aim of securing European and Western values as well as shared interests from the threat of the Islam (Wilders Sets up International Alliance Against Islam, 2010). In several speeches he referred to Muslims within a negative framework. Pop reported that he said: "A new wind will blow in the Netherlands" and "We want the Islamisation to be stopped" (Pop, 2010). He generally underlined the Islamisation of the Netherlands or Islamisation of Europe for the purpose of obtaining the acceptance of the European public for his securitizing acts. He also set a link between Islam and freedom of Europeans in a negative correlation by saying: "I have a problem with the Islamic ideology, the Islamic culture, because I feel that the more Islam that we get in our societies, the less freedom that we get" (Dutch Politician Forms Anti-Islam Coalition, 2010). Moreover, his most important speech was the one in which he claimed: "more security, less crime, less immigration, less Islam - that is what the Netherlands has chosen" (Dutch Election: Liberals Take One-Seat Lead as Far Right Party Grows in Influence, 2010). In that speech, he explicitly established a relationship between migration, crime, security and Islam.

Considering the fact that a vast amount of Turkish population is Muslim, these speeches and anti-immigrant attitudes affect both Turkey's EU candidacy and Turkish migrants in Europe. As Müftüler-Bac argues: "[...] the main obstacle to Turkey's membership in the EU is not the reasons that European officials formally cite - problems related to democracy, economics and human rights - but rather, perceptions of Turkey as alien" (Müftüler-Bac, 2000: 21). More interestingly, she revealed that Turkey had "a more developed market economy than most of" (Müftüler-Bac, 2000: 21) the other candidate countries and "its political problems [were] no worse than those of any other applicants" (Müftüler-Bac, 2000: 21) when Turkey was not accepted as a candidate country at the December 1997 Luxembourg European Council. This shows that a crucial obstacle has been Turkey's identity. The claims that the EU is a Christian club came to the fore as a consequence of the decision taken at the Luxembourg European Council.

Turkey was treated differently from other applicant countries at the Luxembourg European Council. This situation changed at the December 1999 Helsinki European Council when Turkey was declared as a candidate country. However, Turkey was treated differently from the other countries one more time. The reason is that, although Turkey's candidacy was declared, date for the 
initiation of negotiations was not mentioned. Therefore, distrust emerged in Turkey-EU relations. Additionally, before starting negotiations with Turkey, "privileged partnership" was proposed by a number of Member States as an alternative to full membership. Despite such opposition, accession negotiations started with Turkey in October 2005. What is more, even after the accession negotiations were launched, the privileged partnership issue was articulated again by German Chancellor Angela Merkel and French President Nicolas Sarkozy in Berlin in 2009 (Kardaş, 2010). It is noteworthy that, although Turkey started negotiations for the aim of being a full member, such a statement could be made and it caused more distrust between Turkey and the EU. On the other hand, "[t]he 'privileged partnership' has not been mentioned within EU acquis or in any other official documents" (Dedeoğlu and Gürsel, 2010: 3). However, the Negotiation Framework Document of 3 October 2005 included some negative arguments which may be seen as having overtones of the privileged partnership. As Kirişçi states:

The document declared the purpose of the negotiations to be membership and, yet, also
emphasized that negotiations would be open-ended. The document also foresaw the
need to tie Turkey to the EU in the strongest manner possible in the event that the
negotiations did not lead to membership. Such wording had not been adopted in
previous cases of enlargement and have not been adopted for Croatia. This led much of
the Turkish public and as well as Turkish officials to believe that the EU held 'double
standards' and was not committed to Turkey's eventual membership (Kirişçi, 2008: 19).

Considering Müftüler-Bac's abovementioned observation, it may be argued that Turkey is excluded because it has a culturally different identity. Many in Europe believe that if Turkey becomes an EU member, an influx of Turkish workers will be inevitable. They think that, in this sense, this influx will cause integration problems due to Turkey's different culture, religion, heritage and etc. For this reason it can be argued that the EU applies double standards and securitizes Turkish immigration.

Consequently, according to the Copenhagen School's securitization theory, the threat that Europe perceives in this regard seems to be Turkish immigrants; the referent object is Europeans as their cultural identity is at stake; securitizing actors are European leaders and politicians; the audience is nationals of EU Member States; and extraordinary measures are double standards that are applied in Turkey's negotiation process as listed above and some limitations on religious practices and strict visa application rules for Turkish citizens.

\section{Securitization of Migration in Turkey-EU Relations: The Case of Welfare State}

People migrate for several reasons. These are categorized as pull and push factors. Push factors emerge from home country's poor economic, social and political conditions. On the other hand, pull factors are directly related to the host country's welfare, which is an important motivation for people who want to migrate to that country and benefit from social and economic rights of the welfare state. However, citizens of the host country do not want to share these rights with 
migrants. They see migrants as free-riders of benefits of the welfare state. Moreover, they perceive migrants as the welfare state damagers. In this sense, culturally different roots of migrants are used and migrants are classified as the "other". Consequently, "welfare chauvinism" (Huysmans, 2000: 768) emerges. In this case, migrants are seen as a threat both towards cultural homogeneity and the welfare state (Huysmans, 2006: 78). This tendency brings out securitization of migration in the case of the welfare state.

In the context of Turkey-EU relations, the welfare state becomes subject of securitization of migration in two different forms. First are Turkish migrants who are thought to migrate to the EU if Turkey becomes an EU member. Second are asylum-seekers, refugees and illegal immigrants who use Turkey as a transit country on their way to the EU.

In the case of Turkish migration, welfare chauvinism is explicitly seen. Many Europeans tend to see that Turkish migrants have not integrated into host societies especially because of their different culture. Therefore, they do not want to share benefits of the welfare state with those culturally different people. Because of having a huge and young population and high rates of population growth; Europeans believe that Turkey's membership would cause to a huge population movement towards EU countries, which in turn would harm the welfare state. Securitization of migration can clearly be seen in the form of welfare chauvinism. Europeans perceive Turkey's population as a threat in this regard. However, this is not a real, but perceived threat because; Turkey's population has been in transformation. According to the United Nations' projections, Turkey's population growth has shown a decreasing tendency after 1980s and it is estimated that population growth rate would decline to $\% 08$ between the years $2025-2035$ and it would decrease by $\% 2$ between the years 2090-2100 (Türkiye Odalar ve Borsalar Birliği, 2011: 25). As İçduygu and Karaçay state:

By 2050 , it is estimated that while Turkey's population will increase by approximately $40 \%$, the ratio of the $65+$ age group will also double. This transformation will take place especially in the period following the year 2025 following a decline in fertility rates and the aging of the current generations, being replaced by a relatively smaller population. In this context, forecasts estimate that the size of the $65+$ age group, which was 3.6 million in the year 2000, will reach 17 million in 2050. It seems that after the year 2025, Turkey will no longer have a young population" (İçduygu and Karaçay, 2012: 29-30).

Moreover, they argue that, "it is evident that the number of migrants possibly required by the labor force market in the EU cannot be met even in the event of Turkey's entire population migrating to Europe" (İçduygu and Karaçay, 2012: 31). As a matter of fact, Turkey's population might not be a threat to Europe; to the contrary, it might become a remedy for Europe's aging population regarding the internal market and also the welfare state. Europe needs a young working population to protect the welfare state. Additionally, Turkey's membership would ensure more homogeneous Europe, because integration of Turkish migrants would be facilitated with Turkey's membership (Erzan and Kirişçi, 2004: 5). 
In the context of asylum-seekers, refugees and illegal immigrants the situation is a bit different. It seems that the EU tries to establish a dumping ground or a buffer zone to maintain its welfare state. As Kirişçi states:

\begin{abstract}
[Turkish officials] fear that Turkey will become a dumping ground for unwanted immigrants by the EU. Turkish officials are especially concerned because Turkey is encountering great difficulties in initiating negotiations let alone actually concluding [readmission] agreements with many of the sending countries of illegal migrants. They fear that this may lead to a situation where the EU would be able to send back illegal migrants to Turkey while Turkey will not have the means of ensuring their return to their respective countries of origin (Kirişçi, 2004: 8).
\end{abstract}

The EU insists on signing a readmission agreement with Turkey at the expense of Turkey's concerns in this regard. Thus; the aim is explicitly seen in its relations with Turkey. The EU securitizes migration with reference to its welfare, and Turkey faces securitization not only as a sending country but also as a transit country.

The EU asks Turkey to cope with immigration issues in the negotiation process. In the view of the EU, lifting geographical limitations ${ }^{1}$ and signing readmission agreements are important for protecting the welfare state. The reason is that, while the EU tries to secure its welfare, it creates a buffer zone with neighbouring countries against unwanted immigrants. The buffer zone, here, is Turkey. If Turkey lifts the geographical limitation, it has to accept all applications of asylum-seekers. As the first-entry country, Turkey has to ensure protection to asylum-seekers whose applications are accepted by United Nations High Commissioner for Refugees (UNHCR). This situation seems reasonable. However, considering Turkey's geographical location as a bridge between Europe, Africa and Asia, Turkey would become a dumping ground of asylum-seekers and refugees who cannot apply for asylum to the EU (Kirişçi, 2008: 21). In order to eliminate this concern, the EU must adopt a burden-sharing mechanism which will help Turkey to maintain its technical, financial and legislative resources (Baklacioğlu, 2009: 109-110). As Kirişçi states: "Turkish officials will expect to see burden sharing mechanisms that would go beyond what the current Refugee Fund has to offer" (Kirişçi, 2004: 10). On the other hand, "[t]he ultimate 'burden sharing' mechanism is actually the solidarity that is supposed to be embedded in membership" (Kirişçi, 2008: 24). And membership is seen "as the most important manifestation of 'burden sharing"” (Kirişçi, 2008: 21). Additionally, a transitional period regarding resettlement of refugees outside Turkey is expected by Turkish officials; yet, the current aquis does not allow such a practice (Kirişçi, 2007: 335). There are no such mechanisms. Because of the double standards, what exists is distrust among the

\footnotetext{
${ }^{1}$ Turkey signed the United Nations Refugee Convention with "geographical limitation". That is why there are two types of asylum seekers. According to the limitation, Turkey accepts asylum applications only from Europe.
} 
Turkish public and officials towards the EU's approach to Turkey's membership. Therefore, without membership, the burden sharing turns to burden shifting. ${ }^{2}$

On the other hand, signing a readmission agreement with the EU brings additional burden for Turkey. In the case of signing readmission agreement, Turkey has to readmit unwanted migrants who enter to the EU's territory by transiting Turkey. For the EU, it is an important tool in the fight against illegal immigration. However, Turkey can sign readmission agreements with only some origin countries of illegal immigration, thus, Turkey would become a buffer zone for the EU's unwanted migrants if it signs the readmission agreement with the EU.

There is an important phrase in the accession partnership document: "conclude urgently a readmission agreement with Turkey" (Accession Partnership Document, 2008: 51/13). This statement attests to the importance of the situation for the EU. The term "urgently" shows that the EU regards this issue as an emergency one. Additionally, the EU also shows Turkey as a conduit for asylum-seekers and illegal immigrants, indirectly by emphasizing the urgency. Consequently, the EU securitizes migration with reference to welfare, and demands these arrangements from Turkey to deal with migratory threats and uses them as extraordinary measures.

Consequently, in the context of Turkey-EU relations, according to the Copenhagen School's securitization theory, both Turkish immigrants and asylum seekers, refugees and illegal immigrants from third countries are seen as threats; the referent object is the welfare state; securitizing actors are European leaders and politicians; the audience is nationals of EU Member States; and extraordinary measures are arrangements such as the signing of a readmission agreement with the EU and lifting the geographical limitation that are expected from Turkey during the course of the negotiation process.

\section{Conclusion}

This article has attempted to analyse "securitization of migration" in TurkeyEU relations with special reference to the securitization theory of the Copenhagen School. Building on this theory, this article has attempted to show that

\footnotetext{
${ }^{2}$ On the other hand, Greek Minister of Citizen Protection requested from FRONTEX to deploy RABITs at Greece's external border with Turkey in order to prevent illegal immigration. Thus, Turkey as a transit country has been perceived as a threat and RABITs which have been deployed by FRONTEX at Greece-Turkey borders is a clear extraordinary measure. For more information see, "Frontex Deploys Rapid Border Intervention Teams to Greece", Frontex, http://www.frontex.europa.eu/news/frontexdeploys-rapid-border-intervention-teams-to-greece-PWDQKZ, Retrieved on: March 17, 2013.Additionally, Greece decided to build fence at its borders with Turkey for the same reason. Thus, this fence between Turkey and Greece is another extraordinary measure. For more information see, "Greece Plans Turkey Border Fence to Tackle Migration", BBC News, http://www.bbc.co.uk/news/world-europe-12109595, Retrieved on: March 17, 2013, "Fortress Europe: a Greek Wall Close Up", Euobserver, http://euobserver.com/fortress-eu/118565, Retrieved on: March 17, 2013, and also see "Greece's Anti-immigrant Fence", Euronews, http://www.euronews.com/2012/05/10/greece-s-anti-immigrant-fence/, Retrieved on: March 17, 2013.
} 
securitization of migration is a political choice for the EU in its relations with Turkey.

Security and securitization have been studied in order to set theoretical foundation of this article. The Copenhagen School's conception of framing security has been emphasized especially to understand how threats are socially constructed. As noted before, the process of social construction of threats, that is, securitization process starts with speech acts. Therefore, speeches of politicians have been examined in order to see their importance for perceiving something as new threats.

On the other hand, the article has analysed securitization of migration in Turkey-EU relations with reference to three referent objects: internal security, cultural identity and the welfare state. In the case of internal security, the core is the internal market and, as a corollary, the free movement of people. European politicians use a populist rhetoric against Turkey's membership and they securitized migration accordingly. They claim that if Turkey becomes a member, a huge amount of population movement will occur. However, their claims seem to be exaggerated. Several studies have shown such a movement will not occur and even reverse migration will take place as in the cases of Spain, Italy, Portugal and Greece.

In the case of cultural identity, the core is the issue of belonging and Turkey's otherness - especially in terms of religion. Historical images of Turks, Islamic roots of their identity and integration difficulties of earlier Turkish immigrants have come to the fore in this regard. Turks are defined as non-European, other and alien. General belief is that they do not belong to the European society. Therefore, European politicians emphasize those differences in order to gain popular support. They usually behave in accordance with their utilitarian perspectives. In addition, although it is true that the first generation immigrants had some integration difficulties, the second and third generations are well integrated into the host society. Thus, it can be seen that the situation is exaggerated.

In the case of the welfare state, the core is welfare chauvinism that links the welfare state with cultural identity. The predominant conviction is that people who do not belong to the autochthonous society should not be allowed to benefit from economic and social rights of the welfare state. In addition, it must be kept in mind that securitization of migration in the case of the welfare state depends on Turkey's geographical location which is a transit country. Therefore, lifting geographical limitation and signing a readmission agreement have gained prominence. The EU asks Turkey to lift geographical limitation and sign a readmission agreement with it in order to protect European welfare state from asylum-seekers and refugees.

Consequently, it can be said that securitization of migration in Turkey-EU relations is a political choice. This is because, in many cases, securitization is not based on real threats, and some European leaders and politicians exaggerate the situation through their speeches. They do this mainly to get more votes from those 
European people who fear migration for several reasons. However, this situation may change by desecuritization of migration. The past experiences are important to analyse desecuritization of migration. Because, the post-Soviet Union States' accession to the EU did not cause mass migration to Europe unlike many Europeans' suppositions before, the same situation may be valid for Turkey's EU membership. However, some politicians who oppose Turkey's EU membership have used securitization of migration politically. If and when they give up using it, desecuritization process will start. Additionally, in order to ensure desecuritization of migration from Turkey, Europeans must stop declaring it as a threat and they must renounce securitizing migration politically. Actually, the ultimate solution which ensures desecuritization is Turkey's EU membership. 


\section{References:}

Accession Partnership Document, (2008), Official Journal of the European Union, 26 February 2008.

Additional Protocol (1973), Official Journal of European Communities, Vol.16, No C 113/27, $24 \quad$ December 1973, http://eurlex.europa.eu/LexUriServ/LexUriServ.do?uri=OJ:C:1973:113:FULL:EN:PDF, Retrieved on: October 15, 2012.

Ankara (Association) Agreement (1973), Official Journal of European Communities, Vol.16, No C 113/5, 24 December 1973, http://eurlex.europa.eu/LexUriServ/LexUriServ.do?uri=OJ:C:1973:113:FULL:EN:PDF, Retrieved on: October 15, 2012.

Baklacıoğlu, N. Ö., (2009), 'Building 'Fortress Turkey': Europeanization of Asylum Policy in Turkey', The Romanian Journal of European Studies, No.7-8, pp.103-119.

Buzan, B., (2007), People, States \& Fear: An Agenda for International Security Studies in the Post-Cold War Era, $2^{\text {nd }}$ ed., Colchester: ECPR.

Buzan, B., Wæver, O., and de Wilde, J., (1998), Security: A New Framework for Analysis, Lynne Rienner Publishers, Inc., Boulder and London.

Communication from the Commission to the Council and the European Parliament, (2004), 'Recommendation of the European Commission on Turkey's Progress towards Accession', COM (2004), 656 Final, Brussels, 06.10.2004.

Dedeoğlu, B. \& Gürsel, S., (2010), EU and Turkey: The Analysis of Privileged Partnership or Membership, Betam, İstanbul, http://betam.bahcesehir.edu.tr/en/archives/666/eu-andturkey-the-analysis-of-privileged-partnership-or-membership_final, Retrieved on: November 18, 2012.

'Dutch Election: Liberals Take One-Seat Lead as Far Right Party Grows in Influence', (10 June 2010), The Telegraph, http:/www.telegraph.co.uk/news/worldnews/europe/netherlands/7816382/Dutchelection-Liberals-take-one-seat-lead-as-far-right-party-grows-in-influence.html, Retrieved on: January 8, 2013.

'Dutch Politician Forms Anti-Islam Coalition', (16 July 2010), Sky News, http://news.sky.com/story/793070/dutch-politician-forms-anti-islam-coalition,_Retrieved on: January 8, 2013.

Erzan, R. \& Kirişçi, K., (2004), 'Turkish Immigrants: Their Integration within the EU and Migration to Turkey', Turkish Policy Quarterly, Fall 2004, http://www.turkishpolicy.com/images/stories/2004-03-EUodyssey1/TPQ2004-3erzan+kirisci.pdf, Retrieved on: November 13, 2012.

Erzan, R., Kuzubaş, U., and Yıldız, N., (2004), 'Growth and Immigration Scenarios: Turkey-EU', CEPS Turkey in Europe Monitor, No.12, Brussels, pp. 114-125.

Huizinga, Johan.'Wilders Sets up International Alliance Against Islam', (16 July 2010), Radio Netherlands Worldwide, http://www.rnw.nl/english/article/wilders-setsinternational-alliance-against-islam, Retrieved on: January 8, 2013. 
Huysmans, J., (2006), The Politics of Insecurity: Fear, Migration and Asylum in the EU, London: Routledge.

Huysmans, J., (2000), 'The European Union and The Securitization of Migration', Journal of Common Market Studies, Vol.38, No.5, pp. 751-777.

İçduygu, A., (2011), Europe, Turkey and International Migration: An Uneasy Negotiation, Presentation at the Migration Working Group, European University Institute, 26 January 2011.

İçduygu, A. (2009), Turkey: The Demographic and Economic Dimension of Migration, CARIM Mediterranean Migration Report 2008-2009, Fiesole: Italy.

İçduygu, A. \&Karaçay, A. B., (2012), 'Demography and Migration in Transition: Reflections on EU-Turkey Relations', Seçil Paçaci Elitok \&Thomas Straubhaar (eds.), in Turkey Migration and the EU: Potentials, Challenges and Opportunities, Series Edition HWWI, Vol. 5, Hamburg University Press.

Intolerance and Discrimination against Muslim in the EU: Developments since September 2001, (2005), International Helsinki Federation for Human Rights, $\mathrm{http}: / /$ www.art1.nl/nprd/factsheets/Intolerance\%20against\%20muslims\%20in\%20the\%2 0EU\%2003-2005.pdf, Retrieved on: September 21, 2011.

Kardaş, Ş., (2010), 'Merkel and Sarkozy Call for Privileged Partnership Angers Turkey', Publication: Eurasia Daily Monitor, Vol.6, No.92, 13.05.2009, http://www.jamestown.org/programs/edm/single/?tx_ttnews[tt_news] $=34983 \& \mathrm{cHash}=\mathrm{d}$ dff3b536e\#.UbTu3NhApmg, Retrieved on: October 15, 2012.

Kaya, A., (2007), Securitization of Migration in the West and Integration of Migrants, Istanbul Kültür University Conference on "Migration, Turkey and the EU".

Kaya, A.\& Kentel, F., (2005), Euro-Türkler: Türkiye ile Avrupa Birliği Arasında Köprü mü, Engel mi?, İstanbul Bilgi Üniversitesi Yayınları, İstanbul.

Kirişçi, K., (2008), 'Managing Irregular Migration in Turkey: A Political-Bureaucratic Perspective', CARIM Analytic and Synthetic Notes, 2008/61.

Kiriş̧i, K., (2007), 'Turkey: The Political and Social Dimension of Migration', Philip Fargues (ed.), CARIM Mediterranean Migration Report 2006-2007, Fiesole: Italy.

Kirişçi, K., (2004), 'Reconciling Refugee Protection with Efforts to Combat Irregular Migration: The Case of Turkey and the European Union', Global Migration Perspectives, No.11, Global Commission on International Migration, Geneva.

Kirişçi, K., (2003), 'Turkey: A Transformation from Emigration to Immigration', Centre for European Studies, Boğaziçi University: İstanbul, November 2003, http://www.migrationinformation.org/Profiles/display.cfm?ID=176, Retrieved on: March 28, 2013.

Küçük, B., (2011), 'Europe and the Other Turkey: Fantasies of Identity in the Enlarged Europe', Eurosphere Working Paper Series: Online Working Paper, No.34.

Kylstad, I., (2010), 'Turkey and the EU: A 'New' European Identity in the Making', LSE 'Europe in Question' Discussion Paper Series, No.27. 
Lejour, A. M., de Mooij R.A. and Capel C.H., (2004), 'Assessing the Economic Implications of Turkish Accession to the EU', $C P B$ Documents, No.56, The Hague.

Müftüler-Bac, M., (2000), 'Through the Looking Glass: Turkey in Europe', Turkish Studies, Vol.1, No.1, pp. 21-35.

Müftüler-Bac, M., \& Taşkın, E., (2007), 'Turkey’s Accession to the European Union: Does Culture and Identity Play a Role?', Ankara Review of European Studies, Vol.6, No.2, pp. 31-50.

Münevver Cebeci, (2004), 'Multidimensional Security Concept and Its Implications for Post-Cold War Europe and Turkey', unpublished PhD thesis, Marmara University, European Union Institute, İstanbul.

Neumann, I. B., (1999), Use of the Other: "The East” in European Identity, Manchester University Press.

Pop, V., "Dutch Coalition to Target Burqas, Muslim Immigration", (1 October 2010), euobserver, http://euobserver.com/social/30942, Retrieved on: January 8, 2013.

Principles Governing Negotiations, Negotiating Framework, Luxembourg, 3 October 2005.

Rumelili, B., (2008), 'Negotiating Europe: EU-Turkey Relations from an Identity Perspective', Insight Turkey, Vol.10, No.1, pp. 97-110.

Rumelili, B., (2003), 'Liminality and Perpetuation of Conflicts: Turkish-Greek Relations in the Context of Community-Building by the EU', European Journal of International Relations, Vol.9, No.2, pp. 213-248.

Spongenberg, H., 'Populism on the Rise in the Nordic Region', (16 September 2010), euobserver, http://euobserver.com/news/30797, Retrieved on: January 8, 2013.

Türkiye İş Kurumu, 2012 Yillı $\quad$ Tabloları, $\quad$ Tablo 37 , http://www.iskur.gov.tr/KurumsalBilgi/istatistikler.aspx\#dltop, Retrieved on: February $25,2013$.

Türkiye Odalar ve Borsalar Birliği, (2011), 2010 Yılı Uluslararası Nüfus Göstergeleri, Gözden Geçirme Notaları, Sayı: U.17.1/101.

Verney, S., (2007), 'National Identity and The Political Change on Turkey's Road to EU Membership', Journal of Southern Europe and the Balkans, Vol.9, No.3, pp. 213-221.

Wæver, O., (1996), 'European Security Identities', Journal of Common Market Studies, Vol.34, No.1, pp. 103-132.

Wæver, O., (1995), 'Securitization and Desecuritization', in Ronnie D. Lipschutz (ed.), On Security, Columbia University Press, New York.

Williams, M. C., (2003), 'Words, Images, Enemies: Securitization and International Politics', International Studies QuarterlyVol.47, No.4, pp. 513-531. 